\title{
PENGEMBANGAN MINUMAN FUNGSIONAL DARI EKSTRAK KULIT MUNDAR
}

\section{[Development of Red Mangosteen Peel Extracts for Functional Beverage]}

\author{
Faizah Andarini ${ }^{1}$, Sedarnawati Yasni ${ }^{2) \star}$, dan Elvira Syamsir ${ }^{2)}$ \\ 1) Program Studi Ilmu Pangan, Sekolah Pascasarjana, Institut Pertanian Bogor, Bogor \\ 2) Departemen Ilmu dan Teknologi Pangan, Fakultas Teknologi Pertanian, Institut Pertanian Bogor, Bogor \\ Diterima 30 Januari 2018 / Disetujui 4 April 2018
}

\begin{abstract}
Mundar or red mangosteen (Garcinia forbesii) peel has been known to contain various bioactive compounds with antioxidant potential, but research on its utilization is still limited. The aim of this research was to utilize red mangosteen peel for producing a ready-to-drink beverage with superior antioxidant activity and good sensory acceptance. In this study, dried red mangosteen peel (moisture content of 12\%) was extracted with water $(1: 3,1: 5,1: 7$, and 1:10 $\mathrm{w} / \mathrm{v})$ at different temperatures $\left(40\right.$ and $\left.50^{\circ} \mathrm{C}\right)$. The antioxidant potentials of the extracts were compared in terms of their DPPH radical scavenging activities, total phenolic contents, and total monomeric anthocyanin contents. The red mangosteen peel extracted with water at a ratio of $1: 7$ at $40^{\circ} \mathrm{C}$ showed the highest antioxidant activity, i.e. $717.44 \pm 0.44 \mathrm{AAE}$ $\mu \mathrm{g} / \mathrm{mL}, 843.48 \pm 0.77 \mathrm{GAE} \mu \mathrm{g} / \mathrm{mL}$, and $46.55 \pm 0.30 \mathrm{CGE} \mathrm{mg} / \mathrm{L}$, respectively. These extracts were then mixed with corn milk, cinnamon extract and sucralose to develop functional beverages. Three beverage formulas with different concentrations of mundar peel extracts $(5,6$, and $7 \% \mathrm{v} / \mathrm{v})$ were examined by panelists using a hedonic test for their sensory qualities (color, aroma, taste, and mouthfeel). The results suggested that beverage with $6 \%$ mundar peel extracts was the most preferred formula. The total soluble content, $\mathrm{pH}$, viscosity, and $\mathrm{DPPH}$ radical scavenging activity of this preferred formula were $2.98 \pm 0.05^{\circ} \mathrm{Brix}$; $4.32 \pm 0.01 ; 4.93 \pm 0.16 \mathrm{cP}$, and $1025.78 \pm 8.39 \mathrm{AAE} \mu \mathrm{g} / \mathrm{mL}$, respectively.
\end{abstract}

Keywords: anthocyanin, antioxidant, peel extract, phenolic component, red mangosteen

\begin{abstract}
ABSTRAK
Kulit manggis merah atau mundar (Garcinia forbesii) mengandung komponen bioaktif yang memiliki potensi antioksidan, namun belum banyak penelitian tentang pemanfaatannya. Tujuan dari penelitian ini adalah untuk memanfaatkan kulit mundar sebagai produk minuman siap saji yang memiliki kandungan antioksidan tinggi dan penerimaan sensori yang baik. Pada penelitian ini digunakan bahan dasar kulit mundar kering (kadar air 12\% bk) yang diekstraksi dengan air dan beberapa perlakuan, yaitu variasi rasio bahan terhadap pelarut $(1: 3,1: 5,1: 7$, dan $1: 10 \mathrm{~b} / \mathrm{v})$ dan suhu ekstraksi $\left(40\right.$ dan $\left.50^{\circ} \mathrm{C}\right)$. Parameter yang diuji adalah komponen bioaktif berupa aktivitas antioksidan dengan metode penangkapan radikal DPPH, komponen fenolik total dengan reagen Folin-Ciocalteau, dan kandungan antosianin monomerik total. Hasil yang diperoleh adalah antioksidan, komponen fenolik total, dan kadar antosianin paling tinggi didapatkan pada ekstrak dengan perlakuan rasio $1: 7$ dan suhu $40^{\circ} \mathrm{C}$, yaitu berturut-turut sebesar $717,44 \pm 0,44 \mathrm{AAE}$ $\mu \mathrm{g} / \mathrm{mL} ; 843,48 \pm 0,77 \mathrm{GAE} \mu \mathrm{g} / \mathrm{mL}$ dan 46,55 $\pm 0,30 \mathrm{CGE} \mathrm{mg} / \mathrm{L}$. Ekstrak dengan komponen bioaktif tertinggi tersebut kemudian dikembangkan menjadi minuman berbahan dasar sari jagung dengan penambahan ekstrak kayu manis dan sukralosa. Tiga formula minuman dengan variasi konsentrasi ekstrak kulit mundar $(5,6$, dan $7 \% \mathrm{v} / \mathrm{v})$ kemudian diuji organoleptik secara hedonik oleh panelis dengan parameter warna, aroma, rasa, dan mouthfeel. Hasilnya adalah minuman dengan konsentrasi ekstrak kulit mundar $6 \% \mathrm{v} / \mathrm{v}$ paling disukai oleh panelis. Formula ini memiliki total solid sebesar $2,98 \pm 0,05^{\circ} \mathrm{Brix}, \mathrm{pH}$ sebesar $4,32 \pm 0,01$,

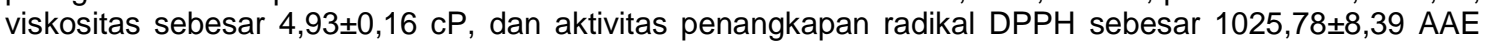
$\mu \mathrm{g} / \mathrm{mL}$.
\end{abstract}

Kata kunci: antioksidan, antosianin, ekstrak kulit, komponen fenolik, mundar

\section{PENDAHULUAN}

Komponen bioaktif seperti vitamin, komponen fenolik, dan flavonoid yang banyak terkandung pada beberapa jenis tanaman merupakan sumber alami yang telah banyak diteliti untuk mendapatkan infor-

*Penulis Korespondensi:

Email: sedarnawati@yahoo.com masi terkait potensi antioksidannya (Nambi et al., 2016). Peningkatan konsumsi atau asupan pangan kaya antioksidan ini telah terbukti dapat meningkatkan kadar antioksidan dalam tubuh serta mengurangi resiko penyakit degeneratif, terutama penyakit kardiovaskuler dan kanker (Do et al., 2014).

Tanaman yang berpotensi sebagai sumber antioksidan salah satunya adalah dari genus Garcinia, termasuk manggis ungu atau yang lebih dikenal de- 
ngan manggis (Garcinia mangostana), serta manggis merah atau yang lebih dikenal dengan mundar (G. forbesii). Komoditas mundar belum banyak dikenal seperti manggis. Mundar memiliki penampakan yang berbeda dari manggis ungu, yaitu buahnya lebih kecil, berdiameter sekitar 3 hingga $5 \mathrm{~cm}$, memiliki kulit tipis dan lunak berwarna merah cerah. Masyarakat biasa mengonsumsi daging buahnya saja dan membuang kulitnya. Namun di beberapa daerah, kulit buah mundar digunakan sebagai obat tradisional, antara lain untuk menyembuhkan infeksi kulit dan inflamasi. Kulit buah mundar juga digunakan sebagai bumbu masak karena memiliki citarasa asam. Selain itu, karena mengandung warna merah yang pekat, kulit mundar juga digunakan sebagai bahan pewarna alami (Neo et al., 2012; Gerten et al., 2015).

Studi fitokimia menunjukkan bahwa Garcinia mengandung berbagai senyawa aktif, diantaranya xanthone. Antioksidan alami ini lebih banyak terkandung dalam kulit buah manggis daripada buah dan bijinya (Jindarat, 2014). Ekstrak kulitnya dilaporkan memiliki efek baik terhadap kesehatan seperti antibakteri, antiinflamasi, dan antifungal. Selain itu, antioksidan pada kulit buah dapat menangkal penyakit kronis seperti serangan jantung, kanker, diabetes, hipertensi, stroke dan penyakit alzheimer (Gutierrezorozco dan Failla 2013; Chitchumroonchokchai et al., 2012). Hasil penelitian oleh Ningsih et al. (2017) menunjukkan bahwa kulit mundar juga memiliki aktivitas antioksidan yang hampir mendekati kulit manggis dan berpotensi untuk dikembangkan sebagai sumber antioksidan, yaitu dalam bentuk minuman siap saji. Permasalahannya adalah ekstrak kulit mundar memiliki rasa sepat dan getir yang cukup kuat (Gupita dan Rahayuni, 2012).

Pemanfaatan ekstrak kulit manggis merah sebagai minuman kesehatan siap saji pernah dilakukan sebelumnya. Randy (2014) mengembangkan minuman ekstrak kulit manggis merah dengan campuran rempah jahe emprit, pekak dan kayu manis, sedangkan Mranani (2015) mencampurnya dengan jeruk nipis dan berbagai rempah. Hasil penilaian oleh panelis menunjukkan bahwa formulasi minuman tersebut memiliki kesukaan "agak tidak suka" hingga "netral" pada parameter aroma dan rasa, sehingga perlu dicari alternatif formulasi ekstrak kulit manggis merah.

Pada penelitian ini, ekstrak kulit mundar dikembangkan menjadi produk minuman fungsional siap saji berbahan dasar sari jagung manis dengan tambahan esktrak kayu manis dan sukralosa sebagai pemanis rendah kalori. Minuman siap saji memiliki kelebihan pada kemudahan dan kepraktisan untuk konsumen, sedangkan penambahan dengan bahan lain bertujuan untuk meningkatkan profil nutrisi serta sensori dari ekstrak kulit mundar. Sari jagung manis digunakan sebagai bahan dasar minuman karena rasanya yang enak dan warnanya yang menarik cukup disukai masyarakat. Selain itu, pada jagung terkandung nutrisi yang dibutuhkan oleh tubuh seperti karbohidrat, serat, protein, serta pigmen karotenoid yang juga berpotensi sebagai antioksidan. Pemanfaatan jagung manis sebagai minuman diharapkan dapat menambah variasi produk berbahan jagung dan meningkatkan nilai ekonomisnya. Penambahan ekstrak kayu manis pada minuman diharapkan dapat memperbaiki profil aroma pada minuman dan memberi aroma khas kayu manis yang disukai oleh masyarakat. Komponen aktif pada ekstrak kayu manis telah banyak diteliti dan berpotensi sebagai antioksidan, sehingga penambahannya saat formulasi diharapkan dapat meningkatkan antioksidan pada produk minuman yang dihasilkan.

Tujuan dari penelitian ini adalah untuk menguji parameter ekstraksi yang optimal dalam menghasilkan ekstrak kulit mundar yang mengandung komponen bioaktif dengan kadar aktivitas antioksidan yang tinggi, serta mendapatkan formulasi minuman berbasis sari jagung, ekstrak kulit mundar, dan ekstrak kayu manis yang tepat, sehingga didapatkan formulasi minuman yang tidak hanya mengandung kadar aktivitas antioksidan yang tinggi namun juga memiliki penerimaan sensori yang baik.

\section{BAHAN DAN METODE}

\section{Bahan}

Bahan yang digunakan pada penelitian ini adalah buah mundar (Garcinia forbesii) yang didapatkan pada Januari 2017 dari Konsultan Buahbuahan Tropis Indonesia. Jagung manis pipilan dan kayu manis didapatkan dari pasar swalayan di Bogor.

\section{Pengeringan kulit mundar}

Buah mundar dipanen pada umur sekitar 60 hari, dengan ciri-ciri warna merah pada kulitnya sekitar $90-100 \%$. Pengeringan diawali dengan pembersihan dan dilanjutkan dengan pemisahan antara bagian kulit dan daging buahnya (Ningsih et al., 2017). Selanjutnya dilakukan pengecilan ukuran dengan pisau, kemudian dikeringkan pada suhu $40^{\circ} \mathrm{C}$ selama kurang lebih 3 jam hingga mencapai kadar air $12 \%$ (pengujian kadar air dilakukan dengan metode gravimetri). Kulit yang telah kering kemudian digiling dengan ukuran 40 mesh, bertujuan untuk menambah luas permukaan bahan sehingga proses ekstraksi dapat berlangsung lebih efektif. Bubuk kulit mundar dikemas dalam plastik rapat dan disimpan dalam refrigerator sebelum digunakan.

\section{Ekstraksi kulit mundar}

Proses ekstraksi kulit mundar yang telah dikeringkan dilakukan dengan teknik maserasi yang dila- 
kukan selama 3 jam pada suhu 40 dan $50^{\circ} \mathrm{C}$, dalam pengaduk waterbath shaker (tipe WNB-7, Memmert, Jerman) (Ningsih et al., 2017). Pelarut yang digunakan adalah air, sedangkan rasio kulit mundar yang digunakan adalah 1:3, 1:5, 1:7, dan 1:10 (b/v) terhadap terhadap pelarut. Proses ekstraksi berlangsung selama 3 jam, kemudian dilakukan penyaringan untuk memisahkan larutan dengan ampasnya. Larutan ektrak kemudian dipekatkan dengan evaporator rotari vakum (Buchi R-300, Swiss) pada suhu $40^{\circ} \mathrm{C}$ hingga mencapai total padatan terlarut sebesar $12^{\circ}$ Brix, lalu dikemas dalam botol gelap rapat dan disimpan dalam refrigerator sebelum digunakan. Ekstrak ini kemudian dianalisis aktivitas antioksidan, komponen fenolik total dan antosianinnya.

\section{Formulasi minuman}

Minuman dibuat dengan proses pencampuran hasil ekstrak kulit mundar dan sari jagung, kemudian ditambahkan ekstrak kayu manis dan sukralosa (Merck, Jerman) sebagai pemanis (Supavititpatana et al., 2008 dan Safithri et al., 2012). Sari jagung dibuat dengan cara merebus jagung pipilan, kemudian dihaluskan dengan penambahan air 3:1 b/v terhadap jagung, lalu disaring dengan kain saring berbahan polyester dengan ukuran 150 mesh. Ekstrak kayu manis dibuat dengan cara merebus kayu manis dalam air dengan rasio air terhadap bahan 5:1 $\mathrm{b} / \mathrm{v}$, kemudian disaring. Volume total dari minuman adalah $250 \mathrm{~mL}$. Variabel yang digunakan adalah konsentrasi ekstrak kulit mundar yang ditambahkan pada sari jagung, yaitu 5,6 , dan $7 \%$ per $250 \mathrm{~mL}$ yang secara berturut-turut disebut formula $A, B$ dan $\mathrm{C}$, sedangkan untuk ekstrak kayu manis dan sukralosa dibuat tetap, yaitu berturut-turut $5 \%$ per $250 \mathrm{~mL}$ dan 200 ppm. Selanjutnya produk dikemas dengan metode pengisian panas dalam kemasan berbahan PET ukuran $200 \mathrm{~mL}$. Ketiga formulasi minuman tersebut kemudian dianalisis aktivitas antioksidan, total padatan terlarut dengan refraktometer tipe $\mathrm{N}-1 \mathrm{E}$ (Atago, Jepang), pH dengan pH meter (Eutech Instruments, Singapura), viskositas dengan viskometer tipe Brookfield RVT (Middleboro, Amerika Serikat), serta karakter warna CIE $L^{*} a^{*} b^{*}$ dengan kromameter tipe CR-310 (Konica Minolta, Jepang). Selain itu minuman juga diuji organoleptik secara penilaian (rating) dan peringkat (ranking) hedonik.

\section{Aktivitas antioksidan}

Pengukuran aktivitas antioksidan dilakukan dengan menggunakan DPPH sebagai radikal (Kubo et al., 2002). Sebanyak $2 \mathrm{~mL}$ larutan buffer asam asetat $(\mathrm{pH} 5,5)$ dicampurkan dengan $3,75 \mathrm{~mL}$ metanol) dan $200 \mu \mathrm{L}$ DPPH 3 mM (Merck), kemudian divortex. Setelah itu ditambahkan ekstrak kulit buah mundar yang telah diencerkan sebanyak 0,06 $\mathrm{mL}$ dan divortex kembali. Larutan ini kemudian diinkubasi pada suhu ruang selama 30 menit pada tempat gelap. Selanjutnya, absorbansi larutan diukur menggunakan spektrofotometer sinar ganda (tipe UV-1800, Shimadzu, Jepang) dengan panjang gelombang $517 \mathrm{~nm}$. Sedangkan untuk pembuatan kurva standar, digunakan larutan standar asam askorbat (Merck) dengan konsentrasi 50 hingga 400 ppm. Larutan blanko dibuat sesuai tahap di atas dengan cara mengganti larutan sampel dengan metanol (Merck). Nilai absorbansi terkoreksi didapatkan dengan perhitungan berikut:

Absorbansi Terkoreksi $=A_{\text {blanko }}-A_{\text {sampel }} \ldots \ldots \ldots \ldots$..... (1)

Perhitungan aktivitas antoksidan dapat dinyatakan dalam Ascorbic Acid Equivalent (AAE, setara asam askorbat) dalam satuan $\mu \mathrm{g} / \mathrm{mL}$ yang didapat dari perhitungan kurva standar.

\section{Analisis komponen fenolik total}

Perhitungan komponen fenolik total dilakukan dengan reagen Folin-Ciocalteau (Boeing et al., 2014). Ekstrak kulit dan yang telah diencerkan sebanyak $250 \mu \mathrm{L}$ dicampurkan dengan reagen Folin-Ciocalteu (Merck) yang telah diencerkan dengan air destilata $1: 1 \mathrm{v} / \mathrm{v}$ sebanyak $250 \mu \mathrm{L}$, kemudian divortex dan didiamkan selama 5 menit. Larutan kemudian ditambahkan $0,5 \mathrm{~mL}$ natrium karbonat $5 \%$ (Setiaguna, Bogor) dan air destilata sebanyak 4.0 $\mathrm{mL}$, kemudian divortex kembali dan diinkubasi selama 1 jam pada tempat gelap. Selanjutnya, absorbansi larutan diukur menggunakan spektrofotometer sinar ganda (tipe UV-1800, Shimadzu) dengan panjang gelombang $765 \mathrm{~nm}$. Untuk pembuatan kurva standar, digunakan larutan standar asam galat (Merck) dengan konsentrasi 10-150 ppm (mg/L). Perhitungan komponen fenolik total dapat dinyatakan dalam Gallic Acid Equivalent (GAE, setara asam galat) dalam satuan $\mathrm{mg} / \mathrm{mL}$ yang didapat dari perhitungan kurva standar.

\section{Analisis kandungan antosianin}

Kandungan senyawa pigmen antosianin dihitung dengan metode perbedaan $\mathrm{pH}$ (AOAC 2005). Sebanyak $4 \mathrm{~mL}$ larutan sampel dimasukkan ke dalam labu takar $25 \mathrm{~mL}$, kemudian ditambahkan larutan buffer hingga batas garis. Untuk mencapai $\mathrm{pH}$ 1,0 sampel ditambahkan buffer $\mathrm{KCl}$ (Merck) $(0,025$ $\mathrm{M})$, sedangkan untuk mencapai $\mathrm{pH}$ 4,5 sampel ditambahkan buffer natrium asetat (Merck) $(0,4 \mathrm{M})$. Keduanya didiamkan selama 15 menit, kemudian diukur menggunakan spektrofotometer sinar ganda (tipe UV-1800, Shimadzu) pada panjang gelombang $520 \mathrm{~nm}$ dan $700 \mathrm{~nm}$. Nilai absorbansi dari kedua pengukuran tersebut kemudian dimasukkan ke dalam persamaan berikut:

$A=\left[\left(A_{520}-A_{700}\right) p H 1-\left(A_{520}-A_{700}\right) p H 4,5\right]$. 
Total antosianin monomerik dihitung sebagai sianidin-3-glukosida, dengan perhitungan berikut:

Total Antosianin $(\mathrm{mg} / \mathrm{L})=$

$$
(\mathrm{A} \times \mathrm{BM} \times \mathrm{FP} \times 1000) /(\varepsilon \times 1)
$$

dimana, A adalah absorbansi sampel, BM adalah berat molekul relatif sianidin-3-glukosida $(448,8$ $\mathrm{g} / \mathrm{mol}$ ), FP adalah faktor pengenceran, dan $\varepsilon$ adalah koefisien ekstingsi molar yaitu $26900 \mathrm{~L} / \mathrm{mol} \cdot \mathrm{cm}$. Kandungan antosianin dinyatakan dalam Cyanidin3-glucoside Equivalent (CGE) setara sianidin-3glukosida dalam satuan $\mathrm{mg} / \mathrm{mL}$.

\section{Analisis organoleptik}

Pengujian organoleptik yang dilakukan berupa uji afektif atau hedonik (Caminiti et al., 2011). Sebanyak 75 panelis tidak terlatih (30 pria dan 45 wanita dengan kisaran umur 17 hingga 30 tahun) diminta untuk menilai atribut dari formula minuman, yaitu warna, aroma, rasa, dan kesan kinestetik pengunyahan makanan dalam mulut (mouthfeel) dengan penilaian hedonik yang disajikan sebanyak 20 $\mathrm{mL}$ pada kondisi dingin (kisaran suhu $4-4,5^{\circ} \mathrm{C}$ ) Skala yang digunakan adalah skala garis sepanjang 10 $\mathrm{cm}$, dimana skala paling kecil bernilai 0 berarti sangat tidak suka, skala 5 berarti netral dan skala 10 berarti sangat suka. Selanjutnya, dilakukan pengurutan peringkat yang bertujuan untuk mengurutkan formula minuman berdasarkan kesukaan dengan parameter keseluruhan.

\section{Analisis statistik}

Percobaan dilakukan dengan rancangan acak lengkap faktorial (2 faktor) dengan kombinasi 2 suhu dan 4 rasio bahan terhadap pelarut. Pada pengukuran aktivitas antioksidan, komponen fenolik total, dan kandungan antosianin ekstrak, percobaan dilakuan dengan pengulangan sebanyak 4 kali, sedangkan pada pengukuran warna, viskositas, total padatan terlarut, $\mathrm{pH}$, dan aktivitas antioksidan pada minuman dilakukan dengan pengulangan sebanyak 3 kali. Pengolahan data dilakukan menggunakan perangkat lunak IBM SPSS Statistics 20 dengan analisis variansi (ANOVA) dan uji lanjut selang ber- ganda Duncan untuk mengetahui perbedaan antar perlakuan pada taraf signifikansi $5 \%$.

\section{HASIL DAN PEMBAHASAN}

\section{Komponen bioaktif kulit mundar}

Hasil pengukuran terhadap aktivitas antioksidan, komponen fenolik total, serta antosianin pada hasil ekstraksi dapat dilihat pada Tabel 1. Selain komponen bioaktifnya, dilakukan juga pengukuran $\mathrm{pH}$ ekstrak. Seluruh ekstrak yang dihasilkan memiliki $\mathrm{pH}$ dengan kisaran 2-2,3. Menurut D'Souza et al. (2017), pangan dengan $\mathrm{pH}$ rendah memiliki kapasitas buffer tinggi karena kandungan asam organiknya yang tinggi, dimana semakin tinggi kapasitas buffer maka waktu yang dibutuhkan untuk perubahan $\mathrm{pH}$ dari kondisi awal lebih lama pula sehingga dapat mengurangi pertumbuhan mikroba.

Suhu merupakan faktor penting dalam proses ekstraksi karena dapat meningkatkan laju perpindahan massa sehingga waktu ekstraksi dapat dikurangi (Oancea dan Drăghici, 2013). Suhu esktraksi mempengaruhi kandungan bioaktif dari ekstrak kulit mundar secara negatif. Perlakuan ekstraksi pada suhu $40^{\circ} \mathrm{C}$ menghasilkan ekstrak dengan kandungan antosianin, komponen fenolik total, dan aktivitas antioksidan yang lebih tinggi daripada perlakuan $50^{\circ} \mathrm{C}$. Hal ini menunjukkan bahwa suhu $40^{\circ} \mathrm{C}$ memiliki resiko kerusakan atau dekomposisi senyawa yang lebih kecil. Hal serupa juga dinyatakan oleh Réblová (2012), dimana peningkatan suhu berbanding lurus dengan penurunan aktivitas antioksidan berbagai macam asam fenolat, meskipun laju penurunannya berbeda-beda. Sebaliknya, tidak semua perlakuan peningkatan suhu dapat menurunkan kandungan bioaktifnya. Pada bahan tertentu, peningkatan suhu dapat meningkatkan pelepasan atau ekstraksi senyawa dengan cara menurunkan fleksibilitas dinding sel atau memperlemah ikatan kimia. Pengaruh panas pada ekstrak air daun pepaya yang dilakukan Vuong et al. (2013) menunjukkan peningkatan aktivitas antioksidan ketika suhu dinaikkan pada kisaran $50-70^{\circ} \mathrm{C}$, kemudian menurun di atas $100^{\circ} \mathrm{C}$.

Tabel 1. Aktivitas antioksidan (penangkapan radikal DPPH), komponen fenolik total, dan komponen antosianin total pada ekstrak kulit mundar yang dihasilkan dari beberapa kondisi ekstraksi

\begin{tabular}{|c|c|c|c|c|}
\hline \multicolumn{2}{|c|}{ Kondisi Ekstraksi } & \multirow{2}{*}{$\begin{array}{l}\text { Aktivitas Antioksidan } \\
\text { (Aae } \mu \mathrm{g} / \mathrm{mL})\end{array}$} & \multirow{2}{*}{$\begin{array}{c}\text { Komponen Fenolik Total } \\
(\text { Gae } \mu \mathrm{g} / \mathrm{mL})\end{array}$} & \multirow{2}{*}{$\begin{array}{c}\text { Komponen Antosianin Total } \\
\text { (Cge Mg/L) }\end{array}$} \\
\hline Suhu $\left({ }^{\circ} \mathrm{C}\right)$ & Rasio (B/V) & & & \\
\hline 40 & $1: 3$ & $587,13 \pm 0,89^{b}$ & $730,16 \pm 1,15^{b}$ & $38,37 \pm 0,06^{b}$ \\
\hline 40 & $1: 5$ & $643,38 \pm 1,77^{d}$ & $823,91 \pm 0,77^{\dagger}$ & $46,13 \pm 0,59^{\mathrm{de}}$ \\
\hline 40 & $1: 7$ & $717,44 \pm 0,44^{g}$ & $843,48 \pm 0,77^{9}$ & $46,55 \pm 0,30^{e}$ \\
\hline 40 & $1: 10$ & $706,19 \pm 2,21^{\dagger}$ & $828,80 \pm 0,77^{\mathrm{n}}$ & $46,03 \pm 0,15^{\mathrm{de}}$ \\
\hline 50 & $1: 3$ & $580,88 \pm 0,88^{a}$ & $691,03 \pm 1,15^{\mathrm{a}}$ & $36,70 \pm 0,41^{a}$ \\
\hline 50 & $1: 5$ & $637,44 \pm 2,21^{\mathrm{c}}$ & $770,65 \pm 0,77^{\mathrm{C}}$ & $45,55 \pm 0,65^{d}$ \\
\hline 50 & $1: 7$ & $706,81 \pm 0,44^{\dagger}$ & $793,21 \pm 0,39^{\mathrm{e}}$ & $45,82 \pm 0,15^{\mathrm{de}}$ \\
\hline 50 & $1: 10$ & $689,94 \pm 0,44^{\mathrm{e}}$ & $776,09 \pm 0,77^{d}$ & $44,57 \pm 0,15^{c}$ \\
\hline
\end{tabular}

Keterangan: Data merupakan nilai rata-rata \pm SD $(n=4)$, huruf yang sama pada kolom menunjukkan tidak berbeda nyata pada taraf signifikansi $5 \%$ (uji selang berganda Duncan) 
Selain suhu, rasio bahan terhadap pelarut juga memberi pengaruh pada kandungan bioaktif ekstrak. Aktivitas antioksidan, komponen fenolik total, dan antosianin pada ekstrak mengalami peningkatan seiring meningkatnya jumlah pelarut yang digunakan. $\mathrm{Hal}$ ini dapat disebabkan karena semakin besar jumlah pelarut maka perbedaan konsentrasi antara senyawa bioaktif dalam bahan dan di pelarut juga semakin besar. Perbedaan konsentrasi yang semakin besar akan meningkatkan kinetika ekstraksi pula (Vuong et al., 2011). Hasil yang sama juga diungkapkan oleh Vuong et al. (2013), yaitu peningkatan massa daun pepaya dalam $100 \mathrm{~mL}$ pelarut akan mengurangi kandungan polifenol dan aktivitas antioksidannya. Penambahan jumlah pelarut meningkatkan nilai komponen bioaktif ekstrak, namun penambahan pelarut menjadi 1:10 tidak terjadi peningkatan. Hal ini dimungkinkan bahwa telah tercapai keseimbangan pada rasio $1: 7$, sehingga penambahan pelarut lebih banyak tidak membuat senyawa yang terekstrak bertambah pula.

Berdasarkan uji statistik, interaksi antara suhu dan rasio mempengaruhi secara signifikan aktivitas antioksidan dan komponen fenolik total ekstrak kulit mundar, namun tidak signifikan pada kandungan antosianin. Hal ini dapat disebabkan karena kestabilan antosianin lebih tinggi pada $\mathrm{pH}$ rendah, dalam hal ini $\mathrm{pH}$ ekstrak yang berkisar antara 2-2,3. Hasil serupa juga didapatkan oleh Oancea dan Drăghici (2013) yang meneliti tentang bawang merah, dimana kandungan antosianinnya stabil pada kondisi asam $(\mathrm{pH}$ 1) dan sangat tidak stabil pada kondisi basa (pH 9). Wahyuningsih et al. (2017) juga menyatakan bahwa antosianin pada ekstrak kelopak bunga mawar lebih stabil pada kondisi asam dan menghasilkan warna kemerahan, dan tidak stabil pada $\mathrm{pH}$ tinggi dan menghasilkan ekstrak dengan warna kebiruan.

Dari hasil tersebut dapat dilihat bahwa aktivitas antioksidan (penangkapan radikal DPPH), komponen fenolik total, dan antosianin tertinggi didapatkan pada perlakuan $40^{\circ} \mathrm{C}$ dan rasio bahan terhadap pelarut 1:7, yaitu berturut-turut $717,44 \pm 0,44 \quad A A E$ $\mu \mathrm{g} / \mathrm{mL}, \quad 843,48 \pm 0,77$ GAE $\mu \mathrm{g} / \mathrm{mL}$ dan $46,55 \pm 0,30$ CGE mg/L. Nilai-nilai ini cenderung berbeda signifikan terhadap perlakuan ekstraksi lainnya. Metode terpilih ini selanjutnya digunakan sebagai bahan dasar untuk fomulasi minuman dari bahan utama sari jagung dan kulit mundar, dengan penambahan ekstrak kayu manis serta pemanis sukralosa.

\section{Karakterisasi formula minuman sari jagung dan kulit mundar}

Pada tahap ini ditentukan tiga formula, yaitu $A$, $B$, dan $C$ yang bervariasi dalam konsentrasi ekstrak kulit mundar yang ditambahkan, yaitu berturut-turut 5,6 , dan $7 \%$ per volume total. Pada penelitian ini, aktivitas antioksidan dinyatakan dengan ekuivalensi asam askorbat atau vitamin C. Pemilihan $7 \%$ ekstrak kulit mundar sebagai konsentrasi paling tinggi adalah berdasarkan penerimaan rasa (organoleptik) pada uji pendahuluan.

Penambahan esktrak kayu manis diharapkan dapat memperbaiki profil aroma ekstrak kulit mundar yang menyengat. Ekstrak kayu manis yang ditambahkan pada minuman sebesar $5 \%$ per volume total. Berdasarkan uji organoleptik pendahuluan, penambahan esktrak kayu manis lebih dari $5 \%$ menghasilkan minuman dengan rasa dan aroma yang tidak menyatu. Penambahan sukralosa diharapkan dapat memberikan citarasa manis pada minuman dan menutupi rasa ekstrak kulit mundar yang sangat asam. Sukralosa memiliki intensitas 600 kali tingkat kemanisan gula sehingga peraturan penggunaanya dalam produk sangat kecil (Ma et al., 2009). Penggunaan maksimal sukralosa yang diijinkan oleh BPOM (2014) pada minuman sari buah adalah 300 ppm. Penambahan sukralosa dibuat tetap, yaitu 200 ppm yang dipilih dari uji organoleptik pendahuluan.

Pengujian beberapa parameter ketiga formula dapat dilihat pada Tabel 2. Dari hasil uji hedonik dapat dilhat bahwa tidak dapat perbedaan yang nyata antara formulasi dengan parameter warna, aroma, serta rasa, namun pada mouthfeel menunjukkan perbedaan yang nyata antara dua dari tiga formula.

Tabel 2. Karakteristik fisikokimia (warna, viskositas, total padatan terlarut) dan aktivitas antioksidan (penangkapan radikal DPPH) formula minuman $A, B$ dan $C$

\begin{tabular}{|c|c|c|c|c|}
\hline \multirow{2}{*}{\multicolumn{2}{|c|}{ Paramater }} & \multicolumn{3}{|c|}{ Formula } \\
\hline & & $A$ & $\mathrm{~B}$ & $\mathrm{C}$ \\
\hline \multirow[t]{4}{*}{ Warna } & $\mathrm{L}^{*}$ & $61,88 \pm 0,92^{b}$ & $56,53 \pm 1,03^{\mathrm{a}}$ & $58,55 \pm 1,35^{\mathrm{a}}$ \\
\hline & $a^{*}$ & $4,93 \pm 0,54^{\mathrm{a}}$ & $9,82 \pm 0,65^{\mathrm{b}}$ & $15,69 \pm 0,49^{c}$ \\
\hline & $b^{*}$ & $56,15 \pm 1.47^{\mathrm{a}}$ & $44,91 \pm 0,14^{\mathrm{b}}$ & $33,63 \pm 0,33^{c}$ \\
\hline & $h^{\circ}$ & $40,98 \pm 0,13^{c}$ & $40,19 \pm 0,32^{b}$ & $27,83 \pm 0,46^{a}$ \\
\hline \multicolumn{2}{|c|}{ Viskositas (cP) } & $7,53 \pm 0,06^{\mathrm{c}}$ & $4,93 \pm 0,12^{b}$ & $3,53 \pm 0,06^{a}$ \\
\hline \multicolumn{2}{|c|}{ Total padatan terlarut $\left({ }^{\circ}\right.$ Brix $)$} & $4,98 \pm 0,10^{c}$ & $2,98 \pm 0,05^{b}$ & $2,80 \pm 0,14^{\mathrm{a}}$ \\
\hline \multirow{2}{*}{\multicolumn{2}{|c|}{$\begin{array}{l}\mathrm{pH} \\
\text { Aktivitas antioksidan (AAE } \mu \mathrm{g} / \mathrm{mL} \text { ) }\end{array}$}} & $4,56 \pm 0,01^{c}$ & $4,32 \pm 0,01^{b}$ & $4,02 \pm 0,01^{\mathrm{a}}$ \\
\hline & & $850,22 \pm 18,95^{\mathrm{a}}$ & $1025,78 \pm 8,39^{b}$ & $1250,22 \pm 11,71^{\mathrm{C}}$ \\
\hline
\end{tabular}

Keterangan: Data merupakan nilai rata-rata $\pm \mathrm{SD}(n=3)$ huruf yang sama pada baris menunjukkan tidak berbeda nyata pada taraf signifikansi $5 \%$ (uji selang berganda Duncan) 
Warna dari ketiga formula berupa warna campuran antara kuning pucat dari sari jagung, merah cerah dari pigmen ekstrak kulit mundar berupa antosianin, dan sedikit tambahan cokelat gelap dari ekstrak kayu manis. Jumlah sari jagung pada formula $A$ paling tinggi dibandingkan formula $B$ dan $C$ sehingga menghasilkan warna yang paling cerah (nilai $L^{*}$ ) dan lebih kuning (nilai $b^{*}$ ). Konsentrasi kulit mundar yang ditambahkan pada formula ini adalah yang paling tinggi dibandingkan formula lain sehingga menghasilkan warna yang lebih merah, ditunjukkan pada nilai $a^{*}$ (warna merah) formula $C$ yang lebih tinggi dibandingkan formula lainnya. Formula $C$ memiliki viskositas paling kecil dibandingkan dengan formula A dan B. Hal ini disebabkan karena konsentrasi ekstrak kulit mundar paling tinggi ditambahkan pada formula $C$. Sari jagung berbentuk larutan yang cukup kental, sedangkan ekstrak kulit mundar berbentuk lebih encer. Jumlah ekstrak kulit mundar pada volume total yang lebih banyak menyebabkan jumlah sari jagung akan lebih sedikit sehingga semakin menurunkan viskositas produk minuman. Jumlah ini juga mempengaruhi kandungan padatan terlarut pada minuman, dimana pada formula $\mathrm{C}$ nilainya paling rendah dibandingkan dengan formula $A$ dan B.

Dibandingkan dengan ekstrak kulit mundar, ketiga formulasi minuman memiliki aktivitas antioksidan yang lebih tinggi. Hal ini dapat disebabkan karena bahan utama lain pembuatan minuman tersebut, yaitu sari jagung manis dan ekstrak kayu manis, juga mengandung komponen bioaktif dengan aktivitas antioksidan. Jagung manis mengandung senyawa pigmen karotenoid berupa lutein dan zeaxanthin yang memiliki aktivitas antioksidan. Pada jagung siap panen, terkandung $11,07 \pm 0,17 \mu \mathrm{g}$ lutein dan $3,71 \pm 0,09 \mu \mathrm{g}$ zeaxanthin pada setiap gramnya ( $\mathrm{Xu}$ et al., 2010). Selain itu, ekstrak air kayu manis telah diketahui memiliki komponen aktif yang larut selama proses ekstraksi, antara lain cinnamaldehyde (63\%), limonen (8\%), eugenol (7\%), cinnamaldehyde propy- lene $(5,5 \%)$ dan beberapa jenis komponen terpenoid lain termasuk a-pinene dan camphene. Komponen aktif ini memiliki potensi antioksidan dan dapat mencegah atau mengurangi kerusakan oksidatif sel (Roussel et al., 2013). Hasil penilaian uji organoleptik oleh 75 panelis tidak terlatih dapat dilihat pada Gambar 1. Dari hasil tersebut dapat dilihat bahwa formulasi tidak berpengaruh secara signikan terhadap parameter warna, aroma, serta rasa namun berpengaruh terhadap mouthfeel. Warna dari suatu produk pangan merupakan pertimbangan utama konsumen dalam memilih suatu produk pangan di antara parameter lain (Winarno, 2008). Dari beberapa komentar panelis, warna kuning-merah pada formula $\mathrm{C}$ dinilai lebih menarik dibanding warna kuning-jingga pada formula $A$ dan $B$, walaupun perbedaannya tidak signifikan. Untuk parameter aroma, penambahan ekstrak kayu manis dapat menutupi sebagian aroma ekstrak kulit mundar memiliki aroma asam yang cukup menyengat pada ketiga formula minuman. Aroma yang dihasilkan dideskripsikan sebagai aroma manis dari sari jagung dan kayu manis yang dapat diterima oleh panelis.

Rasa dari ketiga formula adalah campuran rasa sari jagung yang manis, ekstrak kulit mundar yang asam dan sepat, ekstrak kayu manis serta pemanis berintensitas tinggi sukralosa. Sensasi rasa asam pada produk dipengaruhi oleh $\mathrm{pH}$ atau konsentrasi ion hidrogen dan kandungan asam dalam larutan, dimana intensitas rasa asam meningkat secara linear dengan peningkatan konsentrasi ion hidrogen (Nielsen, 2010).

DeConceicao-Neta et al. (2007) menyatakan hal serupa dimana rasa asam pada acar yang terbuat dari adas sowa (dill) berkolerasi kuat dengan konsentrasi asam organik pada produk. Ekstrak kulit mundar memiliki pH dengan kisaran 2-2,3. Semakin bertambahnya konsentrasi ekstrak kulit mundar menghasilkan $\mathrm{pH}$ produk yang semakin rendah (Tabel 2), dan rasa produk yang semakin asam.

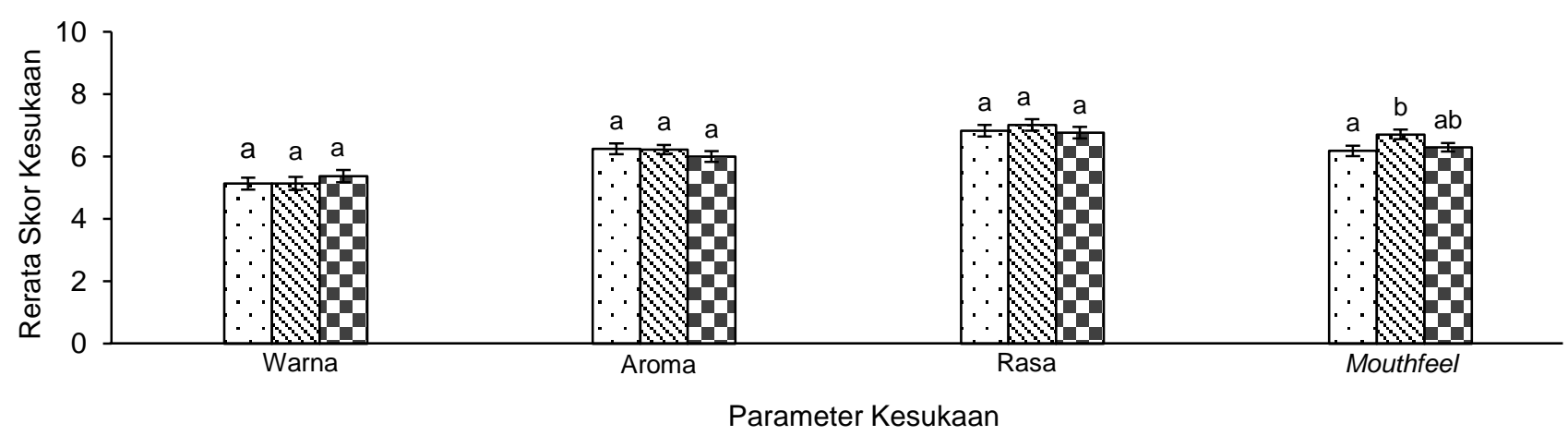

घFormula A $\mathrm{A}$ Formula B $\square$ Formula C

Gambar 1. Nilai hedonik warna, aroma, rasa dan mouthfeel dari formula minuman $A, B$ dan $C(n=75)$, nilai $0=$ sangat tidak suka, 10 = sangat suka, huruf yang sama pada parameter menunjukkan tidak berbeda nyata pada taraf signifikansi $5 \%$ (uji selang berganda Duncan) 
Formula B dideskripsikan memiliki kombinasi rasa manis dan asam yang sesuai, dengan rasa jagung yang dominan dan asam yang menyegarkan. Formula A memiliki rasa jagung yang lebih dominan dan rasa asam yang paling lemah intensitasnya, sedangkan formula $\mathrm{C}$ memiliki rasa asam yang lebih kuat dibandingkan dua formula lain namun tetap menyegarkan. Penambahan sukralosa sebanyak 200 ppm memberi rasa manis dan mampu menutupi sebagian besar rasa sangat asam dari ekstrak kulit mundar sehingga produk lebih dapat diterima oleh konsumen. Sukralosa memiliki kestabilan cukup baik pada suhu tinggi dan pada $\mathrm{pH}$ yang rendah sehingga penurunan intensitas rasa manis pada produk dapat dicegah (Grotz dan Munro, 2009).

Tekstur dan mouthfeel suatu bahan pangan berperan pada penerimaan produk (Stokes et al., 2013). Parameter mouthfeel dari formula minuman didapatkan dari sari jagung yang chalky dan tebal, serta dari ekstrak kulit mundar yang sepat. Pada uji hedonik untuk parameter ini, panelis cenderung menyukai formula B yang tidak terlalu chalky dan tidak terlalu sepat. Jumlah sari jagung yang lebih banyak pada formula A membuat profil mouthfeel yang lebih berasa seperti kapur (chalky) dan tebal (thick). Hal ini dapat disebabkan karena kandungan padatan terlarut pada formula $A$ paling tinggi dibanding formula lainnya. Pada formula $\mathrm{C}$, konsentrasi ekstrak kulit mundar yang lebih tinggi menyebabkan profil mouthfeel dan sisa rasa (aftertaste) sepat yang lebih kuat. Hal ini disebabkan senyawa tanin yang terdapat pada ekstrak kulit yang memiliki citarasa sepat dan getir (Gupita dan Rahayuni, 2012), sehingga semakin banyak konsentrasi ekstrak kulit mundar yang ditambahkan maka minuman akan semakin sepat. Seluruh parameter kesukaan pada ketiga formula memiliki nilai hedonik pada kisaran skala 5 sampai 7 (netral sampai suka) yang berarti penerimaan sensori cukup baik. Selain uji hedonik, panelis juga diminta untuk memilih satu dari ketiga formula tersebut yang paling disukai dengan parameter keseluruhan. Hasilnya dapat dilihat pada Gambar 2.

Dari hasil tersebut dapat dilihat bahwa formula B adalah yang paling disukai oleh panelis, yaitu sebanyak 32 panelis, diikuti formula $C$ sebanyak 24 panelis dan formula A sebanyak 19 panelis. Formula minuman yang paling disukai panelis adalah sari jagung manis dengan ekstrak kulit mundar $6 \% \mathrm{v} / \mathrm{v}$, ekstrak kayu manis 5\% v/v, dan sukralosa 200 ppm. Formula ini memiliki aktivitas antioksidan sebesar $1025,78 \pm 8,39 \mathrm{AAE} \mu \mathrm{g} / \mathrm{mL}$. Jika dikonversikan terhadap massa jenisnya, yaitu $1,06 \mathrm{~g} / \mathrm{mL}$ minuman, maka akan setara dengan 96,77 AAE mg/100 g. Nilai ini lebih tinggi dibandingkan jus buah tropis lainnya, seperti nanas, sirsak, buah asam, dan pepaya yaitu berturut-turut 16,59; 16,94; 47,25; dan 54,00 AAE mg/100 g (Almeida et al., 2011). Kandungan antioksidan pada minuman, selain dari eks- trak kulit manggis, juga bersumber dari bahan sari jagung dan ekstrak kayu manis. Untuk tahap selanjutnya, perlu dilakukan perbaikan proses atau formulasi untuk meningkatkan profil sensorinya, serta pengukuran kinetika kerusakan atau degradasi komponen pada produk minuman untuk mengetahui kestabilannya selama penyimpanan.

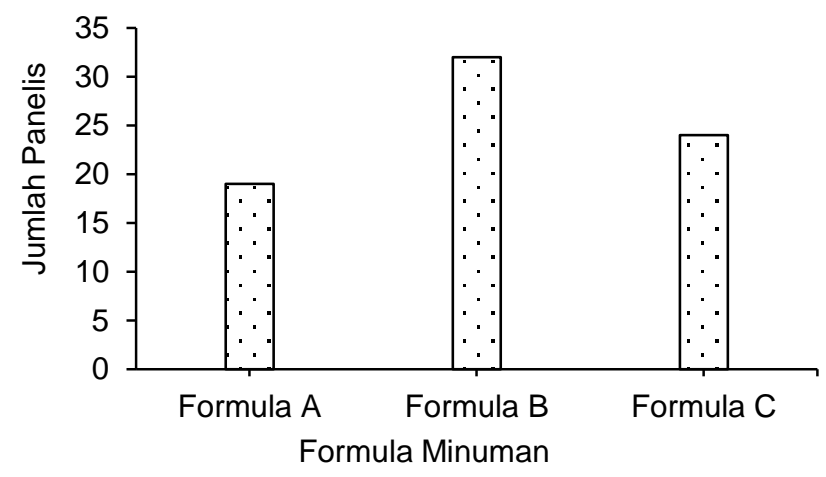

Gambar 2. Preferensi panelis terhadap formula yang paling disukai $(n=75)$

\section{KESIMPULAN}

Kulit mundar berpotensi dikembangkan sebagai sumber antioksidan. Kondisi ektraksi yang tepat untuk mendapatkan komponen bioaktif dari kulit mundar adalah perlakuan suhu ekstraksi $40^{\circ} \mathrm{C}$ dan rasio bahan terhadap pelarut 1:7 (b/v). Formula minuman yang paling disukai panelis adalah sari jagung dengan $6 \% \mathrm{v} / \mathrm{v}$ ekstrak kulit mundar, $5 \% \mathrm{v} / \mathrm{v}$ ekstrak kayu manis, dan 200 ppm sukralosa. Formula tersebut memiliki aktivitas antioksidan sebesar $1025,78 \pm 8,39 \mathrm{AAE} \mu \mathrm{g} / \mathrm{mL}$ dan berpotensi untuk dikembangkan menjadi minuman sumber antioksidan.

\section{DAFTAR PUSTAKA}

[AOAC] Association of Official Analytical Chemists. 2005. Official Methods of Analysis 2005.02. 2005. Total monomeric anthocyanin pigment content of fruit juices, beverages, natural colorants, and wines. J AOAC Int 88: 1269.

Almeida MMB, deSousa PHM, Ariaga AMC, doPrado GM, deCarvalho-Magalhaes CE, Maia GA, deLemos TLD. 2011. Bioactive compounds and antioxidant activity of fresh exotics fruits from northeastern Brazil. Food Res Int 44: 21552159. DOI: 10.1016/j.foodres.2011.03.0 51.

Boeing JS, Barizão ÉO, eSilva BC, Montanher PE. 2014. Evaluation of solvent effect on the extraction of phenolic compounds and antioxidant capacities from the berries: application of principal component analysis. Chem Cent J 8: 1-9. DOI: 10.1186/s13065-014-0048-1. 
[BPOM] Badan Pengawas Obat dan Makanan. 2014. Peraturan kepala badan pengawas obat dan makanan tentang batas maksimum penggunaan bahan tambahan pangan pemanis. http://www.pom.go.id. [22 Desember 2017].

Caminiti IM, Noci F, Muñoz A, Whyte P, Morgan DJ, Cronin DA, Lyng JG. 2011. Impact of selected combinations of non-thermal processing technologies on the quality of an apple and cranberry juice blend. Food Chem 124: 1387-1392. DOI: 10.1016/j.foodchem.2010.07.096.

Chitchumroonchokchai C, Riedl KM, Suksumrarn S, Clinton SK, Kinghorn AD, Failla ML. 2012. Xanthones in mangosteen juice are absorbed and partially conjugated by healthy adults. J Nutr 142: 675-680. DOI: 10.3945/jn.111.1569 92.

D'Souza C, Fernandes R, Kudale S, Naik AS. 2017. Local indigenous fruit derived juices as alternate source of acidity regulators. J Sci Food Agr 98: 1995-2001. DOI: 10.1002/jsfa.8684.

DeConceicao-Neta ER, Johanningsmeier SD, Drake MA, McFeeters RF. 2007. A chemical basis for sour taste perception of acid solutions and fresh-pack dill pickles. J Food Sci 72: 352-359. DOI: 10.1111/j.1750-3841.2007.00400.x.

Do QD, Angkawijaya AE, Tran-Nguyen PL, Huynh LH, Soetaredjo FE, Ismadji S, Ju Y. 2014. Effect of extraction solvent on total phenol content, total flavonoid content, and antioxidant activity of Limnophila aromatica. J Food Drug Anal 22: 296-302. DOI: 10.1016/j.jfda. 2013.11.001.

Gerten D, Salma I, Shafie MSM, Shariah U, Brooke $\mathrm{P}$, Wong WWW, Norhayati MH. 2015. Traditional knowledge and practices related to genus Citrus, Garcinia, Mangifera and Nephelium in malaysia. Open Access Library J 2: 1-11. DOI: 10.4236/oalib.1101453.

Grotz VL, Munro IC. 2009. An overview of the safety of sucralose. Regul Toxicol Pharm 55: 1-5. DOI: 10.1016/j.yrtph.2009.05.011.

Gupita CN, Rahayuni A. 2012. Pengaruh berbagai $\mathrm{pH}$ dan suhu pasteurisasi terhadap aktivitas antioksidan dan tingkat penerimaan sari kulit buah manggis. J Nutr Col 1: 209-215.

Gutierrez-orozco F, Failla ML. 2013. Biological activities and bioavailability of mangosteen xanthones: a critical review of the current evidence. Nutrients 5: 3163-3183. DOI: 10.3390/ nu5083163.

Jindarat S. 2014. Xanthones from mangosteen (Garcinia mangostana): multi-targeting pharmacological properties. J Med Assoc Thai 97: 196-201.
Kubo I, Masuoka N, Xiao P, Haraguchi H. 2002. Antioxidant activity of dodecyl gallate. J Agr Food Chem 50: 3533-3539. DOI: 10.1021/jf011 250h.

Ma J, Bellon M, Wishart JM, Young R, Blackshaw LA, Jones KL, Horowitz M, Rayner CK. 2009. Effect of the artificial sweetener, sucralose, on gastric emptying and incretin hormone release in healthy subjects. Am J Psychol 296: 735739. DOI: 10.1152/ajpgi.90708.2008.

Mranani SA. 2015. Pemanfaatan Potensi Manggis Merah (Garcinia forbesii) sebagai Pengawet Alami dan Minuman Fungsional. [Skripsi]. Bogor: Fakultas Teknologi Pertanian, Institut Pertanian Bogor.

Nambi VE, Gupta RK, Kumar S, Sharma PC. 2016. Degradation kinetics of bioactive components, antioxidant activity, colour and textural properties of selected vegetables during blanching. J Food Sci Technol 53: 3073-3082. DOI: 10.100 7/s13197-016-2280-2.

Neo L, Yee ATK, Chong KY, Yeoh YS, Tan HTW, 2012. The vascular plant flora of abandoned plantations in Singapore I: Clementi forest. Nature Singapore 5: 275-283.

Nielsen SS. 2010. Food Analysis, 4th Edition. 101112. Springer, New York (US). DOI: 10.1007/ 978-1-4419-1478-1.

Ningsih N, Yasni S, Yuliani S. 2017. Sintesis nanopartikel ekstrak kulit manggis merah dan kajian sifat fungsional produk enkapsulasinya. J Teknol Industri Pangan 28: 27-35. DOI: 10.60 66/jtip.2017.28.1.27.

Oancea S, Drăghici O. 2013. pH and thermal stability of anthocyanin-based optimised extracts of romanian red onion cultivars. Czech J Food Sci 31: 283-291. DOI: 10.17221/302/ 2012-CJFS.

Randy M. 2014. Kajian Pemanfaatan dan Pengembangan Potensi Ekstrak Manggis Merah (Garcinia Forbesii) sebagai Minuman Fungsional Kaya Antioksidan dan Kestabilannya. [Skripsi]. Bogor: Fakultas Teknologi Pertanian, Institut Pertanian Bogor.

Réblová Z. 2012. Effect of temperature on the antioxidant activity of phenolic acids. Czech J Food Sci 30: 71-177. DOI: 10.17221/57/2011-CJFS.

Roussel AM, Hininger I, Benaraba R, Ziegenfuss TN, Anderson RA. 2009. Antioxidant effects of a cinnamon extract in people with impaired fasting glucose that are overweight or obese. J Am Coll Nutr 28: 16-21. DOI: 10.1080/07315724. 2009.10719756. 
Safithri M, Yasni S, Bintang M, Ranti AS. 2012. Toxicity study of antidiabetics functional drink of $\mathrm{Pi}$ per crocatum and Cinnamomum burmannii. Hayati J Food Sci 19: 31-36. DOI: 10.4308/hjb. 19.1.31.

Stokes JR, Boehm MW, Baier SK. 2013. Oral processing, texture and mouthfeel: from rheology to tribology and beyond. Curr Opin Colloid In 18: 349-359. DOI: 10.1016/j.cocis.2013.04.0 10.

Supavititpatana $\mathrm{P}$, Wirjantoro TI, Apichartsrangkoon A, Raviyan P. 2008. Addition of gelatin enhanced of corn-milk yoghurt. J Food Chem 106: 211-216. DOI: 10.1016/j.foodchem.2007.05.0 58.

Vuong QV, Golding JB, Stathopoulos CE, Nguyen $\mathrm{MH}$, Roach PD. 2011. Optimizing conditions for the extraction of catechins from green tea using hot water. J Sep Sci 34: 3099-3106. DOI: 10. 1002/jssc.201000863.
Vuong QV, Hirun S, Roach PD, Bowyer MC, Phillips PA, Scarlett CJ. 2013. Effect of extraction conditions on total phenolic compounds and antioxidant activities of Carica papaya leaf aqueous extracts. J Herb Med 3: 104-111. DOI: 10.1016/j.hermed.2013.04.004.

Wahyuningsih S, Wulandari L, Wartono MW, Munawaroh H, Ramelan AH. 2017. The effect of $\mathrm{pH}$ and color stability of anthocyanin on food colorant. Iop Conf Ser-Mat Sci 193. DOI: 10.10 88/1757-899X/193/1/012047.

Winarno FG. 2008. Kimia Pangan dan Gizi. 171172. M-Brio Press, Bogor.

Xu JG, Hu QP, Wang XD, Luo JY, Liu Y, Tian CR. 2010. Changes in the main nutrients, phytochemicals, and antioxidant activity in yellow corn grain during maturation. J Agr Food Chem 58: 5751-5756. DOI: 10.1021/jf100364k. 